\title{
The use of recombinant epidermal growth factor in primary health assistance
}

\begin{abstract}
Introduction: The high morbidity for diabetic foot and its long hospitalization could be solved with the same quality thanks to the level achieved by the Cuban National Health System as well as the proved efficacy of Recombinant Epidermal Growth Factor (EFG) (Heberprot-P) and the training of the personnel who work in the welfare health areas.
\end{abstract}

Objective: To Evaluate the diabetic foot treatment using Heberprot-P in the primary health assistance in Cuba.

Patients \& method: Our universe was composed by 1551patients assisted consecutively in four welfare health areas. All of them received 15 to 24 intralesional injections of $75 \mathrm{micrograms}$ each, three times a week. They were under went to surgical operations when required under nerve trunk anesthesia on the leg. An informed consent was signed previously. The variables analyzed were: Age, sex, Wagner classification, doses administered, surgical procedures and final result.

Results: In our series 407 debridement were carried out (26\%), 77 toe amputations (4, $96 \%)$ and 3 metatarsal amputations $(0,19 \%)$. No major amputations were carried out. A satisfactory granulation was achieved in all patients. The adverse reactions were 17 $(1,1 \%)$ all of them were mild. Nobody quit the treatment and there were no mortality.

Conclusions: Among our patients the treatment were $100 \%$ effective the rate of amputations were low. The adverse events were few and mild.

Keywords: wagner classification, intralesional injection, primary health assistance, heberprot-P
Volume 2 Issue 4 - 2018

\section{Carlos A Del Risco}

Specialist in angiology and vascular surgery, University Hospita Calixto Garcia, Cuba

Correspondence: Carlos A Del Risco, Specialist in angiology and vascular surgery, Consultant professor, University Hospital Calixto Garcia, Havana, Cuba,

Email cdelrisco.cmw@infomed.sld.cu

Received: July 27, 2018 | Published: August 14, 2018

\section{Introduction}

Diabetic foot ulcers (DFU) represent a health problem a word wide. ${ }^{1-3}$ In some countries its treatment is very expensive and not all the citizens can access to medical centers. ${ }^{4,5}$ Since the advent of the epidermal growth factor Heberprot-P a new paradigm has become in DFU treatment. This illness produces a high mortality, morbidity and disability. ${ }^{6,7}$

The patients were referred from primary health physicians. Those who require surgical operations sign an informed consent. The surgical procedures were carried out under nerve trunk anesthesia, according with the site of ulcer. The intraregional injection was performed by personnel trained in the University Hospital three times a week. The patients were evaluated by our doctors weekly through computerized photo program. The adverse reactions were very few. We didn't have quit of the treatment. No major amputations were necessary.

\section{Patients and method}

A longitudinal, retrospective study was carried out including all the patients underwent Heberprot-P Therapy from four primary health areas, assisted consecutively within July 2014 and September 2016. The universe was composed by 1551 diabetic patients suffering gangrene or sole ulcer. All of them were included among stage III or IV of Wagner scale.

They were injected intralesional three times a week with 75 micrograms of Heberprot-p, and evaluated weekly by one specialist of our group who performs the surgical procedures. The operations were carried out in ambulatory system in one operation room at the university hospital.

Inclusion criterion: Patients who didn't have contraindication to use the medicine. Gangrene of toes or sole ulcers. Sign the informed consent. Exclusion criterion: Absolute contraindication to use the product. When major amputation was mandatory. Refusal the treatment. The index of granulation and epithelization was evaluated by computerized photo program created to this purpose.

\section{Results}

In Table 1 we found predominance of females with relationship $55 \%$ to $45 \%$ respect the males. According of age groups among males the main group was 51 to 60 years old while in females was 61 to 70 as other authors said. ${ }^{8}$ According with Wagner scale predominated the neuropathic/infected foot among younger patients, while the olders had mainly ischemic injuries, produced by macroangiopathy as well as microangiopathy.

Above 61years old were seen 388 ulcers Wagner scale IV which represent $86 \%$. Below 70 predominated the Wagner III with 1021patients, they were $93 \%$ like appears in Table 2 we achieved good results in ischemic ulcers as Montequin and cols reported. ${ }^{9,10}$ Majority receive about 15 dosages of the drug like appears in Table 3.

The surgical procedures can be observed in Table 4 among them predominate the debridements $83,57 \%$ we have to point that we 
consider surgical operations such required anesthesia and we didn't include minor procedures. We gave priority to the minimal procedures as sun as possible to resect all the infected areas before the treatment, as appear in the revised literature. ${ }^{11-13}$

All the surgical procedures were performed after the sign the model about informed consent stablished in our hospital. ${ }^{14}$ Almost the third of patients required a minor operation they were enough radical according with the injury and so conservative to archive a functional foot. See Table 4. The end stage of the patients can be seen in Table 5 the results of epithelization and granulation were highly satisfactory.

Table I Patients according age and sex

\begin{tabular}{|c|c|c|c|c|c|c|}
\hline \multirow[t]{2}{*}{ Age groups } & \multicolumn{2}{|c|}{ Male } & \multicolumn{2}{|l|}{ Female } & \multicolumn{2}{|c|}{ Totals } \\
\hline & $\mathbf{N}^{\circ}$ & $\%$ & $\mathbf{N}^{\circ}$ & $\%$ & $\mathbf{N}^{\circ}$ & $\%$ \\
\hline To 50years & 158 & 22,64 & 172 & 20.22 & 330 & 22,64 \\
\hline 51 a 60 & 189 & 27.07 & 233 & 27.26 & 422 & 27.21 \\
\hline 61 a70 & 183 & 26.22 & $24 I$ & 28.22 & 424 & 23.33 \\
\hline 71 a 80 & 123 & 17.62 & 147 & 17.26 & 270 & $|7.4|$ \\
\hline 81 \& more & 45 & 6.45 & 60 & 7.04 & 105 & 6.77 \\
\hline Totals & 698 & 100 & 853 & 100 & $|55|$ & 100 \\
\hline
\end{tabular}

Source: Data base

Table 2 Distribution about Wagner scale

\begin{tabular}{lllllll}
\hline Age groups & \multicolumn{2}{l}{ Wagner III } & \multicolumn{2}{l}{ Wagner IV } & \multicolumn{2}{l}{ Totals } \\
& $\mathbf{N}^{\circ}$ & $\%$ & $\mathbf{N}^{\circ}$ & $\%$ & $\mathbf{N}^{\circ}$ & $\%$ \\
\hline To 50years & 30 I & 9 I,2I & 29 & 8,79 & 330 & 2 I, 26 \\
5I a 60 & 387 & 9 I,7I & 35 & 8,29 & 422 & 27,17 \\
6I a70 & 333 & 78,54 & 9 I & 21,46 & 424 & 27,3 I \\
7I a 80 & 72 & 78,54 & 198 & 73,33 & 270 & 17,37 \\
8I \& more & 6 & $5,7 \mid$ & 99 & 94,29 & 105 & 6,89 \\
Totals & 1099 & $7 \mid$ & 452 & 29 & I55I & 100 \\
\hline
\end{tabular}

Source: Data base

Table 3 Used doses for patient

\begin{tabular}{lll}
\hline \multicolumn{2}{l}{ Used doses for patient } \\
\hline Doses injected & Number & Percent \\
\hline To I5 doses & 739 & 47,65 \\
16 a 19 & 305 & 19,66 \\
20 a 24 & 507 & 32,69 \\
Totals & 1551 & 100 \\
\hline
\end{tabular}

Source: Data base

Table 4 Surgical procedures carried out

\begin{tabular}{lll}
\hline \multicolumn{2}{l}{ Surgical procedures carried out } \\
\hline Type & Number & Percent \\
\hline Debridement & 407 & 83,57 \\
Amputation one toe & 50 & 10,27 \\
Amputation two toes & 27 & 5,54 \\
Metatarsal amputation & 3 & 0,62 \\
Totals & 487 & 100
\end{tabular}

Source: Data base
Table 5 Results at the end of study

\begin{tabular}{lll}
\hline Final evaluation & Number & Percent \\
\hline Partial epithelization & 558 & 35,98 \\
Complete epithelization & 993 & 64,02 \\
Complete granulation & 1551 & 100 \\
\hline
\end{tabular}

Source: Data base

\section{Discussion}

In patients with gangrene we use to demarcate the affected area by infiltration of the drug around it, to take advantage of angiogenic effect of the product after the delimitation, had achieved, the surgical procedure was carried out to remove all the necrotic area.

All patients remain with useful foot for marching, those individuals that required an orthesic device were ordered to make a personalized shoe. Some of them required tenotomies or single arthrodesis to achieve an optimal feet to avoid recidivism similar to Lewis recommend. ${ }^{8}$

Photometric evaluation was performed weekly by one of our specialist and recorded in a data base, to evaluate exactly the progress. About one third of our patients required a minor amputation but major wasn't needed. An evaluation of amputation risk was performed in each patient as recommended Khan and others. ${ }^{15-16}$

Al comorbidities were evaluated by a multidisciplinary team like appears in some bibliographies. ${ }^{17-19}$ In our opinion the extension of diabetic foot treatment to primary health care is highly satisfactory if the personnel is previously educated and checked closely.

\section{Wagner scale}

i. Grade 0 Risk foot. Thick callus. Prominent metatarsal bones heads, claw toes, bone deformities.

ii. Grade I. Superficial ulcer, whole destruction of the skin, superficial cellulitis.

iii. Grade II. Uncomplicated deep ulcer which affects skin, tendons, fat, ligaments, without osteomyelitis.

iv. Grade III. Complicated deep ulcer, extensive area, discharge puss, osteomyelitis and abscess.

v. Grade IV. Limited gangrene, partial necrosis of the foot.

vi. Grade V. Extensive gangrene all the foot affected and systemical effects. $^{20-22}$

\section{Acknowledgements}

None.

\section{Conflict of interest}

The author declares no conflict of interest.

\section{References}

1. Weledji EP, Fokam P. Treatment of the diabetic foot to amputate or not? BMC Surg. 2014;14:83.

2. Gupta SK, Singh SK. Diabetic foot: a continuing challenge. Adv Exp Med Biol. 2012;771:123-138. 
3. Gessmann J, Citak M, Fehmer T, et al. Ilizarov external frame technique for pirogoff amputations with ankle disarticulation and tibiocalcaneal fusion. Foot Ankle Int. 2013;34(6):856-864.

4. Widgerow AD. Bioengineered skin substitute considerations in the diabetic foot ulcer. Ann Plast Surg. 2013;73(2):239-244.

5. Pankhurst CJW, Edmonds ME. Barriers to foot care in patients with diabetes as identified by healthcare professionals. Diabet Med. 2018;10.1111/dme.13653.

6. Reynaldo Concepción D, Álvarez Duarte H, Llanes Barrios JA, et al. Conducta práctica y paradigmas quirúrgicos que ha modificado el Heberprot-P. Rev Cubana Angiol y Cir Vasc. 2012;10(1).

7. Llanes JA, Álvarez HT, Toledo AM, et al. Manual para la prevención, diagnóstico y tratamiento del pie diabético. Rev Cubana Angiol y Cir Vasc. 2012;10(1).

8. Lewis J, Lip A. Pressure-relieving interventions for treating diabetic foot ulcers. Cochrane Database Syst Rev. 2013;(1):CD002302.

9. Fernández Montequín JI, Mena G, Santisteban Y. Tratamiento y recuperación del pie diabético Grado $\mathrm{V}$ de la clasificación de Wagner tras aplicar el Heberprot P. Biotecnología Aplicada. 2010;27(2):110-112.

10. Fernández Montequín JI, Santisteban Bonachea Y. ¿Puede el Heberprot-P cambiar conceptos quirúrgicos en el pie diabético? Biotecnología Aplicada. 2010;27(2):159-164.

11. Kono Y, Muder RR. Identifying the incidence of and risk factors for reamputation among patients who underwent foot amputation. Ann Vasc Surg. 2012;26(8):1120-1126.

12. Weck M, Slesaczeck T, Paetzold H, et al. Structured health care for subjects with diabetic foot ulcers results in a major reduction of amputation rates. Cardiovascular Diabetology. 2013;12(1):45.
13. Senneville E, Nguyen S. Current pharmacotherapy options for osteomyelitis: convergences, divergences and lessons to be drawn. Expert Opin Pharmacotherapy. 2013;14(6):723-734.

14. Del Risco Turiño C. El Consentimiento Informado en las Amputaciones Mayores de Miembros Inferiores. Un estudio de caso. Ed Verlag, Editorial Académica Española; 2017.

15. Khan T, Shin L, Woelfel S, et al. Building a scalable diabetic limb preservation program: four steps to success. Diabet Foot Ankle. 2018;9(1):1452513

16. Boyko EJ, Seelig AD, Ahroni JH. Limb- and person-level risk factors for lower-limb amputation in the prospective seattle diabetic foot study. Diabetes Care. 2018;41(4):891-898.

17. Papatheodorou K, Banach M, Bekiari E, et al. Complications of diabetes 2017. J Diabetes Res. 2018;3086167:4.

18. Zelen CM, Serena TE, Gould L, Le L, et al. Treatment of chronic diabetic lower extremity ulcers with advanced therapies: a prospective, randomized, controlled, multi-center comparative study examining clinical efficacy and cost. Int Wound J. 2016;13(2):272-282.

19. Long M, Rojo de la Vega M, Wen Q, et al. An essential role of NRF2 in diabetic wound healing. Diabetes. 2016;65(3):780-793.

20. Wagner FW. The dysvascular foot: a system for Diagnosis and treatment. Foot ankle. 1981;2(2):64-122.

21. Rutherford RB, Jones DN, Bergentz SE, et al. Factors affecting the patency of infra inguinal bypass. J Vasc Surg. 1988;8(3):236-246.

22. Wagner FW. The diabetic foot. Orthopedics. 1987;10(1):163-171. 